\author{
BARBARA WĄSOWICZ, MARIANNA SOROKA \\ Katedra Genetyki \\ Wydziat Biologii Uniwersytetu Szczecińskiego \\ ul. Felczaka 3c, 71-412 Szczecin \\ e-mail: marianna.soroka@usz.edu.pl
}

\title{
TECHNIKA LAMP JAKO POTENCJALNE NARZECDZIE W ANALIZACH KRYMINALISTYCZNYCH
}

\section{WSTEP}

Jednym z największych osiagnięć biologii molekularnej jest odkrycie łańcuchowej reakcji polimerazy, czyli metody PCR (ang. polymerase chain reaction) przez Kary'ego B. Mullisa w 1983 r., za co w 1993 r. otrzymał nagrodę Nobla. Po raz pierwszy technikę PCR wykorzystano w celach identyfikacyjnych na potrzeby sądu już w 1986 r. Miało tego miejsce w Pensylwanii i był to pierwszy przypadek, gdy sąd zaakceptował materiał genetyczny jako dowód w sprawie (RUDIN i INMAN 2001). Zaleta techniki PCR jest możliwość przeprowadzenia badań genetycznych nawet $z$ niewielkiej ilości wyjściowego materiału biologicznego. Reakcja PCR umożliwia powielenie dowolnego fragmentu DNA w przeciagu 2-3 godzin. Ze względu na swe zalety i liczne modyfikacje, stała się podstawowym narzędziem badawczym w wielu laboratoriach naukowych, diagnostycznych i kryminalistycznych. Pewne modyfikacje tej metody poprawiaja jej czułość (nano PCR) i specyficzność (nested PCR), pozwalaja na analizę przyrostu produktów w czasie rzeczywistym (Real-Time PCR), umożliwiaja amplifikację wielu fragmentów genomu jednocześnie (multiplex PCR) oraz bardzo długich jego fragmentów (long PCR). Wszystkie odmiany reakcji PCR przebiegaja cyklicznie w ściśle określonych etapach termicznych, obejmujących denaturację podwójnej nici DNA (w temperaturze $92-98^{\circ} \mathrm{C}$ ), hybrydyzację starterów do komplementarnych zasad DNA $\left(42-68^{\circ} \mathrm{C}\right)$ i specyficzna elongację łańcucha DNA $\left(72^{\circ} \mathrm{C}\right)$. Taki przebieg reakcji wymaga użycia specjalistycznego sprzętu (tj. termo- cyklera) oraz dużo czasu, potrzebnego nie tylko na sam przebieg reakcji PCR, ale także na otrzymanie izolatów DNA niezbędnych do jej przeprowadzenia. Istnieje kilka sprawdzonych metod izolacji DNA (metoda fenolowo-chloroforomowa, kolumnowa czy solna), które dobiera się w zależności od rodzaju materiału jakim dysponujemy. Pomimo pewnych różnic w protokołach podanych wyżej izolacji, każda $z$ nich jest czasochłonna, najdłuższa może trwać nawet do 3 dni, a najkrótsza 2 godziny (MALEWSKA 2005).

\section{TECHNIKA LAMP}

W 1998 r. japońska firma Eiken Chemical Co., Ltd. opracowała metodę amplifikacji izotermicznej za pośrednictwem pętli, nazwanej technika LAMP (ang. loop-mediated isothermal amplification), eliminujac tym samym pewne trudności, które pojawiały się przy zastosowaniu reakcji PCR (NOTOMI i współaut. 2000). W Polsce nieliczne firmy zajmuja się dystrybucją odczynników do tej metody i przykładowo sa to: A\&A Biotechnology i Novazym. Technika LAMP jest wysoce specyficzna metoda amplifikacji DNA, pozwalajacca na skuteczne zwiększenie ilości namnażanego DNA nawet do $10^{9}$ kopii w czasie krótszym niż 1 godzina, w porównaniu do $10^{6}$ kopii uzyskiwanych w reakcji PCR. Amplifikacja izotermiczna może być przeprowadzona bez potrzeby użycia zaawansowanego sprzętu laboratoryjnego $\mathrm{np}$. w łaźni wodnej lub w bloku grzejnym. Nowatorskim elementem techniki LAMP jest także zwiększona specyficzność, która wynika z zastosowania kilku par starterów (od 3 


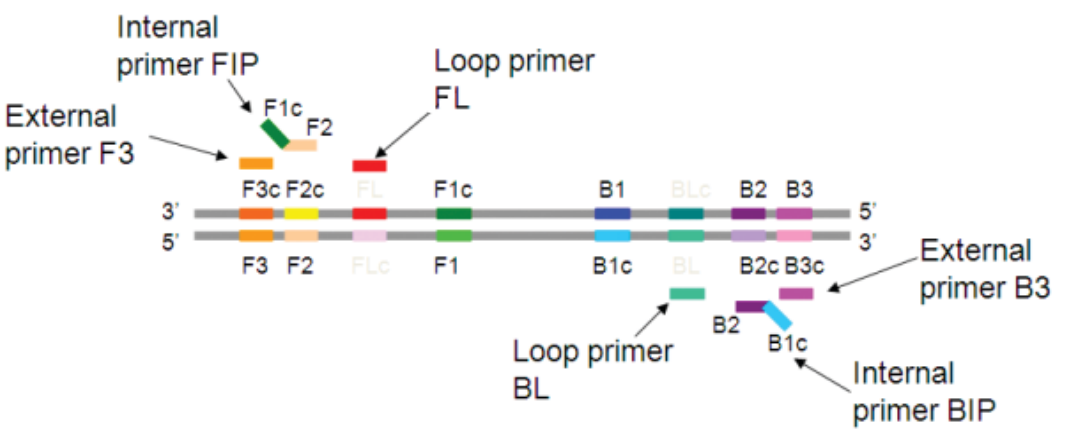

Ryc. 1. Startery wykorzystywane w reakcji LAMP.

Internal primer FIP - Starter wewnętrzny Forward, zawiera region F2 komplementarny do F2c matrycy oraz wolny region F1c komplementarny do F1 na nowej powstałej nici; Internal primer BIP - Starter wewnętrzny Reverse, zawiera region B2 komplementarny do B2c matrycy oraz wolny region B1c komplementarny do B1 na nowej powstałej nici; External primer F3 - Starter zewnętrzny Forward, zawiera w swojej sekwencji region F3 komplementarny do F3c matrycy; External primer B3 - Starter zewnętrzny Reverse, zawiera w swojej sekwencji region B3 komplementarny do B3c matrycy; Loop primer FL - Starter zapętlający Forward, komplementarny do jednoniciowej pętli pomiędzy regionami F2 i F1; Loop primer BL - Starter zapętlający Reverse, komplementarny do jednoniciowej pętli pomiędzy regionami B2 i B1. Zgodnie z: Novazym Skrypt nr 4/2014.

do 4), pozwalających rozpoznać od 6 do 8 specyficznych miejsc na matrycy DNA, a nie tylko dwóch jak w typowej reakcji PCR.

Startery wykorzystywane $\mathrm{w}$ reakcji LAMP (Ryc. 1) możemy podzielić na parę starterów zewnętrznych (ang. forward primer, F3; backward primer, B3), długie startery wewnętrzne (ang. forward inner primer, FIP; ang. backward inner primer, BIP) oraz startery zapętlające (ang. loop primers: loop primer BL i loop primer FL). Sekwencje starterów wewnętrznych, mające ok. 45-49 par zasad (pz) są komplementarne do dwóch odległych miejsc w sekwencji matrycy (na nici sensownej $\mathrm{i}$ antysensownej), one inicjuja syntezę DNA oraz tworza struktury pętli. Natomiast startery zewnętrzne komplementarne sa do zewnętrznych końców matrycy i inicjuja reakcję zastępowania nici (ang. strand displacement). Startery zewnętrzne sa krótsze, mają ok. 21-24 pz i występuja w mieszaninie reakcyjnej $\mathrm{w}$ mniejszym stężeniu, aby wiazały się $z$ matryca wolniej niż dłuższe startery wewnętrzne. Proces zastępowania nici prowadzi do uwolnienia pojedynczych nici DNA, służących jako matryce dla drugich wewnętrznych oraz zewnętrznych starterów, które syntetyzuja charakterystyczne struktury DNA zwane spinka do włosów (ang. stem-loop). Dodatkowym elementem sa startery zapętlajace, komplementarne do utworzonych wcześniej pętli, zwiększajace ilość „punktów startowych” w reakcji LAMP
(NAGAMINE i współaut. 2002). Dzięki tym starterom wydajność i czułość reakcji znacznie wzrasta, a czas amplifikacji ulega skróceniu nawet o połowę. Przebieg reakcji LAMP możliwy jest dzięki zastosowaniu polimerazy posiadajaccej aktywność wypierania nici, co umożliwia pominięcie etapu denaturacji matrycy DNA w wysokiej temperaturze $\left(92-98^{\circ} \mathrm{C}\right)$. Pozwala to na przeprowadzenie reakcji $\mathrm{w}$ warunkach izotermicznych (Notomi i współaut. 2000, NAGAmine i współaut. 2001).

\section{PRZEBIEG REAKCJI LAMP}

Technike LAMP można podzielić na 3 etapy: tworzenie materiału startowego do reakcji LAMP, cykliczna amplifikację, a następnie elongacje $i$ recyklizację. Najważniejszym elementem jest utworzenie $\mathrm{w}$ pierwszym etapie sztucznej matrycy $\mathrm{w}$ postaci jednoniciowego DNA o strukturze typu spinki do włosów (ang. stem-loop) (Ryc. 2-6). Startery wewnętrzne, flankujace nowopowstała nić, maja wolne końce komplementarne do sekwencji nici, co prowadzi do utworzenia pętli na jej końcach. Następne etapy polegaja na amplifikacji tej matrycy dzięki ponownemu działaniu starterów wewnętrznych, samopowielaniu się matrycy (ang. self-priming template) oraz zastępowaniu nici, co skutkuje powstaniem mieszaniny dwuniciowego DNA (Ryc. 7). Powstałe struktury składaja się $z$ powielonych pętli formowanych $z$ połączenia starterów $\mathrm{z}$ naprzemiennymi po-

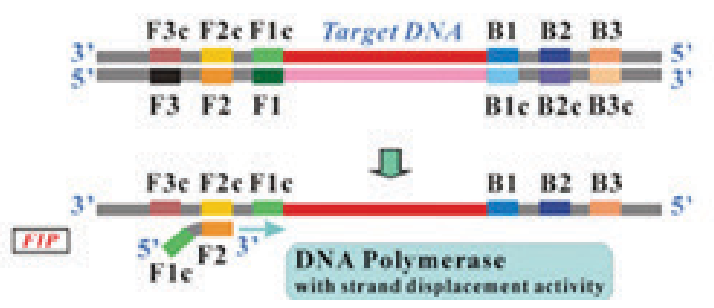

Ryc. 2. Starter wewnętrzny FIP komplementarny do sekwencji F2c matrycy, przyłącza się i inicjuje syntezę nici DNA przy udziale polimerazy DNA o właściwościach wypierania nici (DNA Polymerase with strand displacement activity). Zgodnie $z$ : Novazym Skrypt nr 4/2014. 


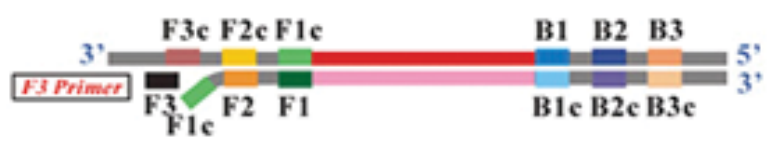

Ryc. 3. Nowopowstała podwójna nić DNA, będąca efektem wydłużania wewnętrznego startera FIP. Następnie starter zewnętrzny F3 (F3 Primer) przyłącza się do miejsca F3c matrycy i amplifikuje DNA uwalniając pojedynczą nić DNA. Zgodnie $z$ : Novazym Skrypt nr 4/2014.

a

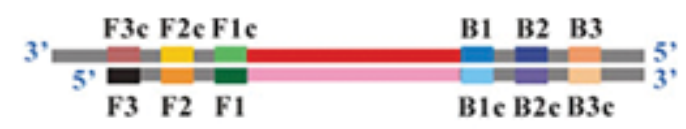

b

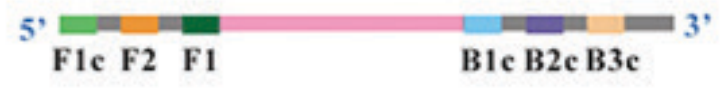

Ryc. 4. Produkty powstałe w skutek wydłużania zewnętrznego startera F3: a) podwójna nić DNA, b) pojedyncza nić oflankowana starterem FIP (F1c, F2). Zgodnie z: Novazym Skrypt nr 4/2014.

wtórzeniami nici docelowej. Oprócz zastosowania 4 starterów rozpoznajacych 6 miejsc docelowych, we wstepnych etapach LAMP można użyć dodatkowej pary starterów zapętlających, pozwalających na zwiększenie miejsc startowych syntezy DNA i skrócenie czasu całej reakcji amplifikacji (Ryc. 8). Dodatkowo użyte startery zapętlajace sa aktywne dopiero wówczas, gdy zostanie wytworzona sztuczna matryca o strukturze spinki do włosów, co znacznie zwiększa selektywność amplifikacji. W efekcie końcowym tworzą się struktury podobne do kalafiora (ang. cauliflower-like structures), co ilustruje Ryc. 9. Wszystkie etapy reakcji przebiegaja w stałej temperaturze ok. 60$70^{\circ} \mathrm{C}$, dlatego nie ma potrzeby użycia termocyklera zapewniajacego precyzyjna zmianę profili termiczno-czasowych, koniecznych w przypadku przebiegu typowej, czy zmodyfikowanej reakcji PCR. Brak konieczności użycia zaawansowanej aparatury umożliwia przeprowadzenie reakcji LAMP w warunkach pozalaboratoryjnych, co w przypadku kryminalistyki jest niezwykle przydatne. Natomiast w przypadku standardowej reakcji PCR jest to niemożliwe lub niezwykle trudne do wykonania.

Najistotniejszym, a zarazem najtrudniejszym elementem, odpowiedzialnym za

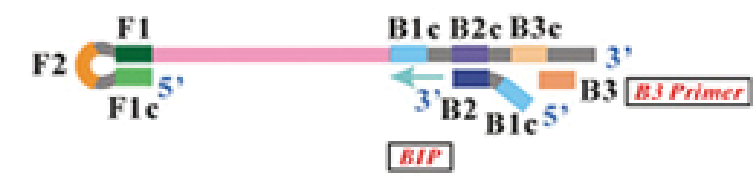

Ryc. 5. Starter wewnętrzny BIP przyłącza się w drugim końcu nici DNA do miejsca B2c na matrycy DNA i rozpoczyna syntezę. Starter zewnętrzny B3 (B3 Primer) przyłącza się do miejsca B3c matrycy wypierajac nić DNA, powstała $\mathrm{w}$ wyniku syntezy ze starterem BIP. Zgodnie z: Novazym Skrypt nr 4/2014.

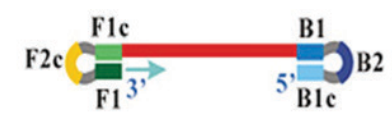

Ryc. 6. Schemat jednoniciowego DNA o strukturze spinki do włosów, czyli sztuczna matryca do dalszej reakcji amplifikacji technika LAMP. Zgodnie z: Novazym Skrypt nr 4/2014.

prawidłowy przebieg reakcji LAMP, jest poprawne zaprojektowanie kilku par starterów. Startery te w temperaturze $60-70^{\circ} \mathrm{C}$ muszą mieć strukturę jednoniciowa i nie moga tworzyć stabilnej formy dwuniciowej. Większa liczba starterów stosowanych do amplifikacji jednej sekwencji może zwiększać interakcje między nimi. Ponadto, wybór starterów wymaga wcześniejszej analizy zmienności wielu sekwencji genowych badanego gatunku czy gatunków w zależności od celu przeprowadzania reakcji LAMP. W przypadku braku takich informacji konieczne jest poznanie poziomu zmienności wybranego genu w gatunku lub gatunkach poprzez technikę sekwencjonowania, co znacznie wydłuża czas i nakłady pracy przygotowujace do techniki LAMP.

Kolejnym minusem techniki LAMP jest brak możliwości sprawdzenia, czy w danej próbie znajdują się inhibitory reakcji. W tym celu konieczne jest przeprowadzenie dwóch reakcji, jednej w celu detekcji inhibitorów i drugiej w celu amplifikacji. Pomimo tego, że technika LAMP jest doskonałym narzędziem diagnostycznym, jej produkty nie nadaja się do dalszych analiz, takich jak klonowanie, czy sekwencjonowanie produktu (SAHOO i współaut. 2016). Produkty docelowe reakcji LAMP sa krótkie i w związku $z$ tym każde zanieczyszczenie próby egzogennym materiałem genetycznym może negatywnie wpływać na wynik reakcji. Należy mieć dużą świadomość ryzyka kontaminacji próby i konieczności zachowania szczególnych procedur sterylności. 


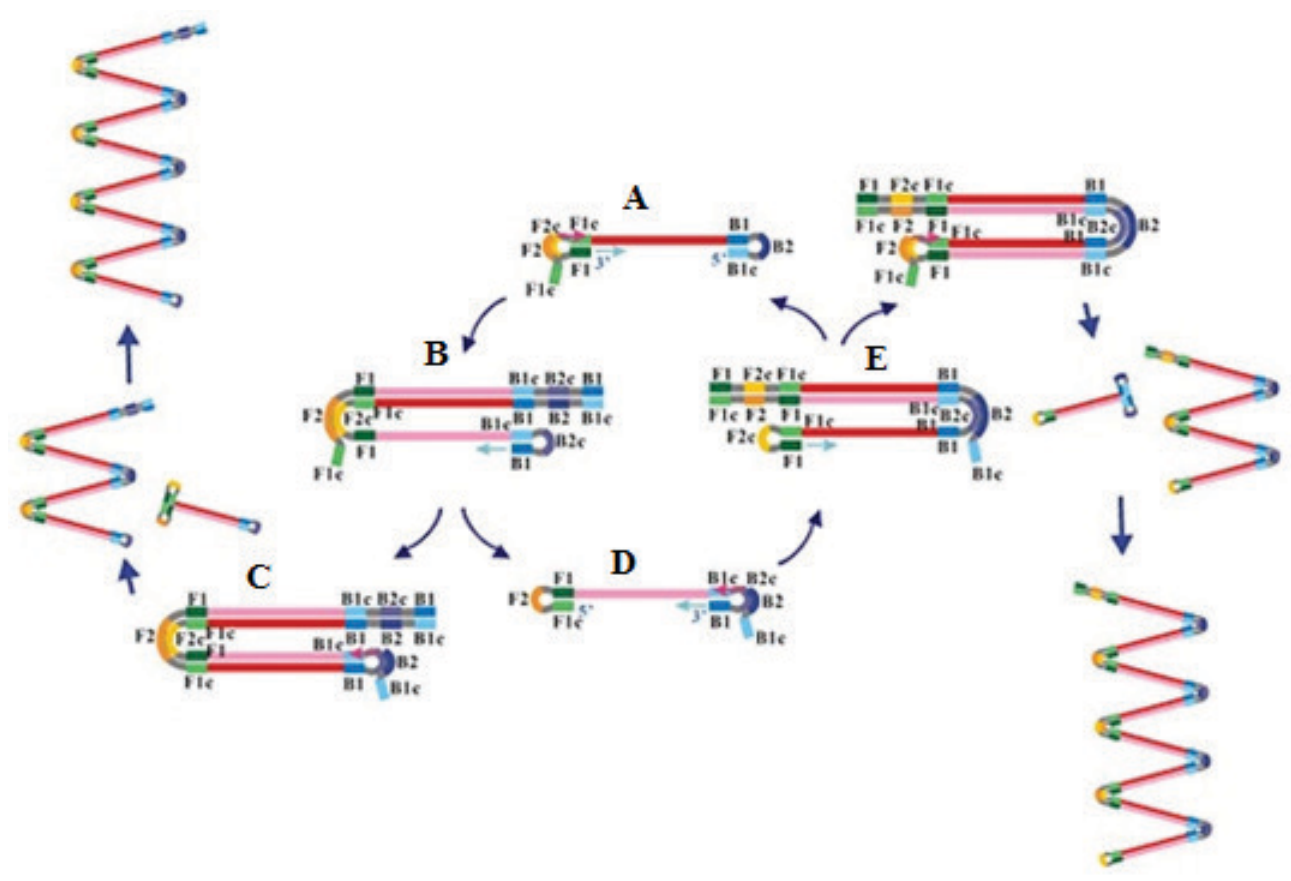

Ryc. 7. Samopowielanie się matrycy z udziałem starterów wewnętrznych (FIP i BIP). W wyniku etapów A-E powstaja produkty składające się $z$ na przemian odwróconych powtórzeń sekwencji matrycowej na tym samym łańcuchu. Zgodnie z: Novazym Skrypt nr 4/2014.

a

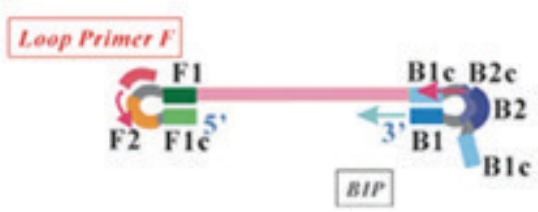

b

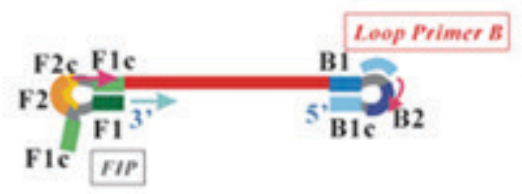

Ryc. 8. Sztuczne matryce DNA o strukturze spinki do włosów: a) Starter zapętlający F (Loop Primer F) hybrydyzuje do komplementarnego miejsca matrycy pomiędzy regionami F1 i F2, b) Starter zapętlający B (Loop Primer B) hybrydyzuje do komplementarnego miejsca matrycy pomiędzy regionami B1 i B2. Zgodnie z: Novazym Skrypt nr $4 / 2014$.

\section{DETEKCJA PRODUKTÓW REAKCJI LAMP}

Klasyczna amplifikacja technika PCR (z wyjątkiem Real-Time PCR) musi być zakończona rozdziałem elektroforetycznym otrzymanych produktów (elektroforeza agarozowa lub poliakrylamidowa). Zarówno przygotowanie żelu (agarozowego lub poliakryloamidowego), jak i sam rozdział elektroforetyczny sa czasochłonne, a wizualizacja wyników wymaga użycia barwników, które nierzadko sa mutagenne i kancerogenne. Reakcja LAMP pozwala na detekcję produktów kilkoma szybkimi metodami. Produkty te moga być nawet obserwowane ,gołym okiem” zaraz po zakończeniu reakcji, bąd́ jeszcze w trakcie jej przebiegu bez zastosowania dodatkowych procedur. Niezwykle szybka i nie wymagająca zaawansowanych urządzeń jest analiza turbidymetryczna (MORI i współaut. 2001). Powstający $\mathrm{w}$ trakcie reakcji LAMP produkt uboczny, pirofosforan magnezu, pozwala na ocenę wyniku poprzez analizę zmętnienia roztworu reakcyjnego i wówczas produkt reakcji może być widoczny bez konieczności użycia jakiegokolwiek dodatkowego sprzętu. Widoczne zmętnienie oznacza obecność produktu reakcji, a brak zmętnienia świadczy o jego braku. Osad (zmętnienie) powstaje $\mathrm{w}$ trakcie reakcji przyłączania kolejnych nukleotydów do wydłużanego łańcucha DNA. Podczas tej syntezy uwalniany jest pirofosforan $z$ dNTP (nukleotydów przyłaczanych do nowo powstajacego łańcucha). Duża ilość powstającego piroforsforanu reaguje $\mathrm{z}$ jonami magnezu obecnymi $\mathrm{w}$ buforze reakcyjnym, tworzac wspomniany osad. Zmętnienie w probówce jest widoczne, gdy stężenie pirofosforanu magnezu przekracza 0,5 mM. Taka analiza w przypadku reak- 


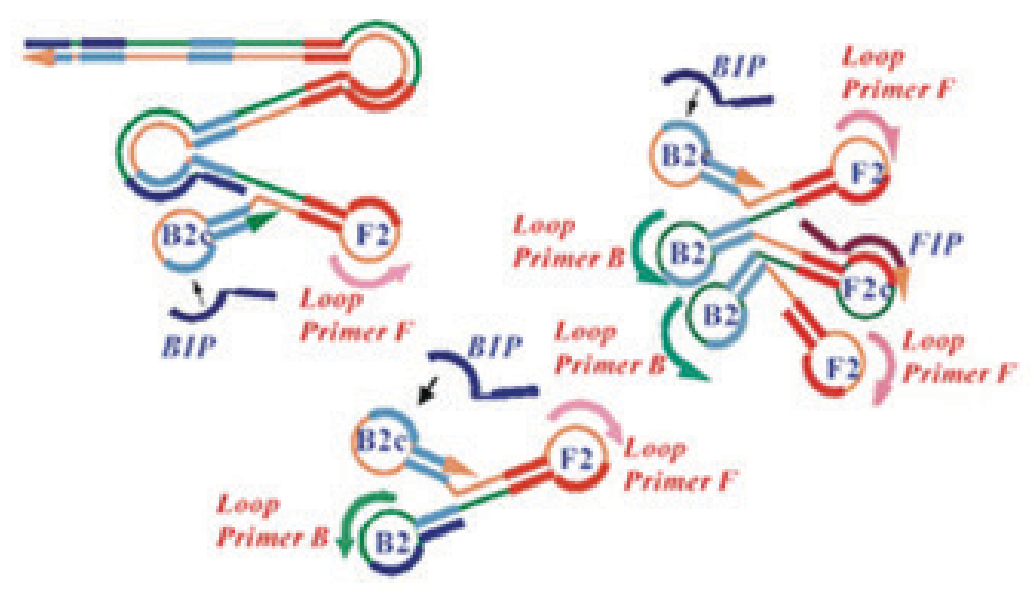

Ryc. 9. Schemat struktur podobnych do kalafiora, powstających w trakcie cyklicznej amplifikacji LAMP przy użyciu starterów wewnętrznych (FIP i BIP) i dodatkowo zapętlajacych (Loop primer F i Loop primer B). Zgodnie z: Novazym Skrypt nr 4/2014.

cji PCR jest niemożliwa ponieważ stężenie pirofosforanu magnezu wynosi zaledwie ok. 0,02 mM. Warunki termiczne, a dokładnie denaturacja przebiegajaca $\mathrm{w}$ temperaturze ok. $95^{\circ} \mathrm{C}$, w reakcji PCR powoduje, że jony pirofosforanowe sa hydrolizowane do jonów fosforanowych. Analiza zmętnienia pozwala na ocenę jakościowa produktu. Natomiast w celu analizy ilościowej, metode LAMP można połączyć $z$ analizą w czasie rzeczywistym. Określana jest wówczas zależność pomiędzy ilościa powstającego pirofosforanu magnezu, a ilościa powstającego DNA.

Inna metoda oceny jakościowej produktów reakcji LAMP jest detekcja fluorescencji barwników emitujących światło o określonej długości fali po związaniu się $z$ podwójna nicia DNA. Do najczęściej stosowanych barwników fluorescencyjnych należą: bromek etydyny, SYBR Green czy Eva-Green, dzięki którym wynik może być obserwowany w świetle UV. Metodę te można połaczyć $z$ analiza w czasie rzeczywistym, pozwalajaca także na ocenę ilościową produktu (MORI i współaut. 2004).

Pozytywny wynik reakcji LAMP możemy także sprawdzić stosując klasyczną elektroforezę $\mathrm{w}$ żelu agarozowym. W przeciwieństwie do obrazu charakterystycznego dla typowej reakcji PCR, wynik reakcji LAMP widoczny jest $\mathrm{w}$ postaci prążków różnej długości. Powodem takiego obrazu jest różna długość i struktura otrzymanych produktów DNA.

\section{WYKORZYSTANIE TECHNIKI LAMP}

Metody molekularne oparte o klasyczną reakcję PCR wymagaja specjalistycznego sprzętu oraz znacznego czasu do uzyskania wyniku. Amplifikacja izotermiczna za pośrednictwem pętli pozwala znacznie skrócić czas analiz i dlatego stała się jednym ze standardowych narzędzi w laboratoriach diagnostycznych. Technika LAMP zyskuje coraz większe zastosowanie $\mathrm{w}$ diagnostyce nie tylko ludzkich, ale także i zwierzęcych chorób zakaźnych. Metoda ta dzięki swej czułości pozwala na identyfikację drobnoustrojów nawet $z$ bardzo niewielkiej ilości materiału badawczego $\left(10^{-15} \mathrm{~g}\right)$ (DHAMA i współaut. 2014). Powszechne stosowanie tej techniki w laboratoriach diagnostycznych jest możliwe dzięki dostępności na rynku sprawdzonych starterów do wykrywania wirusów, bakterii, grzybów i pasożytów wywołujących choroby u ludzi (np. SARS, zapalenie watroby typu B, gruźlica), zwierzat (np. grypa typu H5N1, pryszczyca) oraz roślin uprawnych i ozdobnych (IMAI i współaut. 2007, CAI i współaut. 2008, PRZYBYLSKA i współaut. 2015, BUDZISZEWSKA i współaut. 2016).

Technika LAMP znalazła swoje zastosowanie także w przypadku przestępstw gospodarczych. Przemysł spożywczy boryka się z licznymi oszustwami ze strony producentów jeśli chodzi o skład gatunkowy sprzedawanych mięs i wyrobów mięsnych. Drogie mięsa zostaja zastapione tańszymi zamiennikami, np. zamiast wołowiny czy baraniny sprzedawana/używana jest wieprzowina. Dotychczasowe metody badań przetworzonych produktów mięsnych (kiełbas, pasztetów czy suszonego mięsa) opieraja się o analizę białek, które łatwo ulegają denaturacji pod wpływem obróbki termicznej, soli czy ciśnienia, co uniemożliwia ich detekcję. Najlepsza alternatywa okazała się amplifikacja kwasów nukleinowych, a dokładnie DNA mitochondrialnego (mtDNA), gdyż genom ten jest mniej podatny na degradację niż DNA jądrowy. Umożliwia to analizę gotowanych lub przetworzonych produktów mięsnych pod katem zawartości mtDNA $z$ różnych zwierząt. Do tego typu analiz najczęściej wykorzystuje się analizę mitochondrialnych genów: cytochromu b (cytb) i oksydazy cytochromowej podjednostki I i II (cox1 i cox2) oraz niekodujacego regionu D (ang. D-loop) (DoOLEY i współaut. 2004). Szeroka skala przestępstw w sektorze przetwórstwa mięsnego doprowadziła do opracowania komercyjnych zesta- 
wów służacych do identyfikacji 8 gatunków mięsa ( $z$ krowy, świni, kaczki, kury, konia, owcy, kozy i indyka) przy użyciu techniki LAMP. Analizy te można przeprowadzić w ciagu 30 minut uzyskując większa skuteczność niż w przypadku wykorzystywanej dotychczas reakcji PCR i jej odmian (AE-RI i współaut. 2014).

Diagnostyka patogenów roślinnych ma duże znaczenie ekonomiczne. Klasyczne metody służace identyfikacji charakteryzuja się niska czułościa i czasochłonnościa (np. w przypadku bakterii konieczne jest prowadzenie hodowli kultur wyizolowanych bakterii). Czułość detekcji została znacznie poprawiona dzięki analizie kwasów nukleinowych przy użyciu reakcji PCR. Jednak i ta metoda nie jest pozbawiona wad. Konieczność stosowania drogich termocyklerów, ograniczona wydajność czy specyficzność reakcji to jedne $z$ nich. W diagnostyce chorób roślin ważna jest możliwość natychmiastowego przeprowadzenia testów pozwalających uzyskać potrzebne informacje, nawet w warunkach polowych. Technika LAMP jest idealnym rozwiazaniem do tego typu analiz. Pierwsza praca opisująca wykorzystanie techniki LAMP $\mathrm{w}$ detekcji chorób roślin została opublikowana już w 2003 r. przez FUKUTA i współautorów. Dotyczyła ona detekcji japońskiego wirusa mozaiki jama (ang. Japanese yam mosaic virus, JYMV) przy wykorzystaniu odmiany techniki LAMP, czyli RT-LAMP (ang. reverse transcription loop mediated isothermal amplification). RT-LAMP, podobnie jak RT-PCR, pozwala na syntezę komplementarnych odcinków DNA (ang. complementary DNA, cDNA) na sekwencji RNA, co umożliwia szybka, prosta i bardzo czuła identyfikację RNA wirusów, stanowiacych poważna grupę patogenów roślin, np. fasoli (WEI i współaut. 2012), dyni (WANG i współaut. 2014), pomidorów (PRZEWODOWSKA i współaut. 2015), czy wiśni (ZONG i współaut. 2014). Liczba publikacji dotyczących tego tematu ciagle wzrasta. Szybkość i swoistość testów wykonywanych dzięki reakcji LAMP pozwala na przeprowadzenie analiz nawet $\mathrm{w}$ miejscu produkcji, co pozwala na natychmiastowe wycofanie produktu, zapobiegając tym samym rozprzestrzenianiu się patogenu (HARPER i współaut. 2010). Metoda LAMP pozwala na szybka detekcję chorób roślin o szerokim znaczeniu ekonomicznym, powodowanych przez bakterie: Xyllella fastidiosa (HARPER i współaut. 2010), Erwinia amylovora (MORADI i współaut. 2012), Ralstonia solanacearum (KUBOTA i współaut. 2008).

Istotne znaczenie gospodarcze mają także organizmy genetycznie modyfikowane (ang. genetically modified organisms, GMO), w których identyfikacji technika LAMP okazała się niezwykle skuteczna (LEE i współaut. 2009a). Opracowano procedurę składajaca się $z$ szybkiej ekstrakcji DNA $z$ modyfikowanych genetycznie roślin poprzez mechaniczną macerację tkanki w wodzie. Pominięto $\mathrm{w}$ ten sposób długotrwały etap oczyszczania, który był konieczny w przypadku innych metod molekularnych np. reakcji PCR. Pomimo zastosowania nieoczyszczonego materiału biologicznego, otrzymano pozytywne wyniki genotypowania technika LAMP, co umożliwia zastosowanie tej metody nawet w warunkach polowych (LEE i współaut. 2009b).

Identyfikacja gatunkowa roślin przy użyciu techniki LAMP znalazła także zastosowanie $\mathrm{w}$ zielarstwie. Metody identyfikacji ziół w oparciu o morfologie czy obserwacje mikroskopowe dość często okazuja się niewystarczajace. Dostępnych jest wiele publikacji dotyczacych wykorzystania techniki LAMP do analizy roślin leczniczych, np. odróżnienie żeńszenia właściwego od roślin podobnych nie mających właściwości terapeutycznych (SASAKI i współaut. 2008, CHAUDHARY i współaut. 2011).

\section{LAMP W KRYMINALISTYCE}

Technika LAMP może znaleźć szerokie zastosowanie w kryminalistyce ze względu na swe zalety i powszechność stosowania, o czym świadcza liczne publikacje naukowe cytowane powyżej. Metoda LAMP jest bardzo obiecujaca alternatywa dla standardowej reakcji PCR, a dodatkowo jak wynika $z$ literatury, w niektórych przypadkach przewyższa nawet czułość metody Real-Time PCR, powszechnie wykorzystywanej $\mathrm{w}$ laboratoriach kryminalistycznych (NAGAMINE i współaut. 2002). W porównaniu do klasycznej reakcji PCR, metoda LAMP jest dużo mniej wrażliwa na substancje hamujące amplifikację, zawarte $\mathrm{w}$ materiałach biologicznych (KANEKO i współaut. 2007). Daje to możliwość pominięcia niekiedy etapu izolacji DNA czy dodatkowego oczyszczania materiału biologicznego, co pozwala na zaoszczędzenie zarówno czasu, jak i nakładu pracy oraz kosztów. Opisane sa przypadki, w których pominięto typowa izolacje DNA zastępujac ja maceracja tkanki w wodzie, inkubacja $\mathrm{w}$ temperaturze $95^{\circ} \mathrm{C}$, a następnie schłodzeniem mieszaniny w lodzie. Tak powstałe izolaty wykorzystano do dalszej reakcji LAMP, otrzymując pozytywne wyniki, które były porównywalne do prób otrzymanych $z$ materiału po typowej izolacji DNA (PRZYBYLSKA i wspołaut. 2015).

Już w 2008 r. japońscy naukowcy wykorzystali technikę LAMP do ustalenia płci człowieka. Analizie podlegał jadrowy gen 
amelogeniny, a materiał badawczy stanowiły miazgi $z 32$ zębów liczacych nawet 25 lat (NoGAMI i współaut. 2008). Czas wykrycia odpowiednich alelli na chromosomie $\mathrm{X} i$ Y, określających płeć, wynosił ok. 30 minut. Detekcja produktów reakcji LAMP była możliwa bez konieczności użycia jakiegokolwiek sprzętu, ze względu na pojawiajace się zmętnienie $\mathrm{w}$ roztworze. W przypadku gdy materiał dowodowy stanowia kości, określenia płci dokonuje się w oparciu o ich morfologię, jednak w przypadku kości dzieci przed okresem dojrzewania jest to niemożliwe, nawet dla doświadczonych antropologów. W takich sytuacjach analiza genetyczna jest jedynym rozwiązaniem, a możliwość przeprowadzenia jej w krótkim czasie jest dużym atutem techniki LAMP i $z$ pewnościa będzie szybko wykorzystana do analiz dowodów sadowych.

Często spotykanym problemem w badaniach kryminalistycznych jest bardzo mała ilość dostępnego materiału biologicznego oraz ustalenie, czy jest on pochodzenia ludzkiego czy nie. W tym celu opracowany został test łaczacy amplifikację DNA przy użyciu metody LAMP $z$ reakcja kolorymetryczna $z$ nanocząsteczkami złota (WATTHANA-PANPITUCK i współaut. 2014). Zaprojektowane startery rozpoznaja aż 8 regionów ludzkiego genu mitochondrialnego - cytochromu b, a specyficzność reakcji została sprawdzona względem wyników uzyskanych dla 11 gatunków zwierząt, w tym blisko spokrewnionych $z$ człowiekiem tj. szympansem i orangutanem. Wyniki reakcji LAMP były obserwowane poprzez zmianę koloru roztworu. Metoda ta okazała się być solidnym, konkretnym i mało kosztownym narzędziem dla kryminalistyki dzięki możliwości identyfikacji ,śladów” człowieka. Dotychczasowe liczne badania kolorymetryczne moga wskazywać zwykle na rodzaj badanej substancji, ale nie pozwalają na określenie jej przynależności gatunkowej tylko do człowieka. Standardowe testy immunologiczne służące do wykrywania ludzkiej krwi moga dawać pozytywne wyniki w przypadku krwi naczelnych i członków rodziny łasicowatych (łasica, borsuk). Ponadto, analizy ludzkich mitochondrialnych markerów DNA oparte na reakcji PCR (pętla D oraz geny: cytochrom b i $16 \mathrm{~S}$ rDNA) wymagaja użycia zaawansowanych instrumentów laboratoryjnych, a cały proces zajmuje co najmniej 3-4 godziny, nie uwzględniajac izolacji DNA. Dostęp do prostego narzędzia umożliwiajacego rozróżnienie płynów pochodzenia nie od ludzi ma wielkie znaczenie dla kryminalistyki. Dodatkowo skrócenie czasu analiz jest niezwykle ważne w przypadku, gdy ma to istotne znaczenie w postępowaniu sądowym.

\section{PODSUMOWANIE}

Technika LAMP jest idealna odpowiedzia na rosnace zapotrzebowanie ze strony laboratoriów molekularnych, diagnostycznych, a także kryminalistycznych. W porównaniu do standardowych metod amplifikacji (reakcji PCR wraz $z$ jej modyfikacjami), LAMP pozwala przeprowadzić cała reakcję w stałej temperaturze i w krótkim czasie bez konieczności użycia zaawansowanej aparatury. Ponadto, w porównaniu do reakcji PCR pozwala na otrzymanie większej ilości produktu i jego detekcję, gołym okiem" bez użycia dodatkowych procedur. Użycie od 3 do 4 par starterów $\mathrm{w}$ technice LAMP zwiększa szybkość i specyficzność syntezy DNA. Pomimo występujących pewnych ograniczeń, liczne zalety tej techniki sprawiaja, że stosowana w badaniach kryminalistycznych może mieć w przyszłości ogromne znaczenie dla wymiaru sprawiedliwości. Zwiększająca się liczba publikacji naukowych jest dowodem użyteczności i skuteczności tej metody w różnych dziedzinach. Obecność na rynku dużej liczby gotowych, sprawdzonych zestawów komercyjnych wykorzystywanych do detekcji patogenów ludzkich, daje szansę na szybką diagnostykę chorób nawet ,,przy łóżku pacjenta”. Identyfikacja zakażeń roślin przy użyciu techniki LAMP może pozwolić na szybkie przeniesienie organizmu do kwarantanny i uniknięcie dużych strat ekonomicznych. Popularność jaka technika LAMP osiaga w różnych, praktycznych dziedzinach pozwala sacdzić, że jej wykorzystanie w kryminalistyce także okaże się skuteczne i powszechne.

\section{Streszczenie}

Amplifikacja w warunkach izotermicznych (technika LAMP) jest idealna odpowiedzia na rosnace zapotrzebowanie ze strony laboratoriów molekularnych, diagnostycznych, a także kryminalistycznych. Technika LAMP jest atrakcyjna alternatywa dla klasycznej reakcji PCR, a jej użycie pozwala na skrócenie czasu analizy nawet trzykrotnie. Polimerazy wykorzystywane do tego typu amplifikacji maja zdolność wypierania nici DNA, co eliminuje konieczność denaturacji matrycy. Dzięki użyciu kilku par starterów w reakcji LAMP, przeprowadzona amplifikacja jest bardziej specyficzna, a także w porównaniu do reakcji PCR pozwala na otrzymanie większej ilości produktu i jego detekcję bez użycia dodatkowych procedur i sprzętu. Technika LAMP zyskuje znaczenie w takich dziedzinach jak: przestępstwa gospodarcze, diagnostyka ludzkich i zwierzęcych chorób zakaźnych, detekcja patogenów roślinnych o szerokim znaczeniu gospodarczym czy identyfikacja roślin GMO.

\section{LITERATURA}

AE-Ri CH., HeE-Jin D., SEOngBeOM CH., 2014. Meat species identification using loop-mediated isothermal amplification assay targeting 
species-specific mitochondrial DNA. Korean J. Food Sci. Anim. Resour. 34, 799-807.

BUDZISZEWSKA M., WIECZOREK P., OBREPALSKA-STEPLOWSKA A., 2016. One-step reverse transcription loop-mediated isothermal amplification (RT-LAMP) for detection of tomato torrado virus. Arch. Virol. 161, 1359-1364.

Cai T., Lou G., Yang J., Xu D, Meng Z., 2008. Development and evaluation of real-time loop-mediated isothermal amplification for hepatitis $B$ virus DNA quantification: a new tool for HBV management. J. Clin. Virol. 41, 270-276.

Chaudhary A. A., Heman T., Mohsin M., AhMAD A., 2011. Application of loop-mediated isothermal amplification (LAMP)-based technology for authentication of Catharanthus roseus (L.) G. Don. Protoplasma 249, 417-722.

DHAMA K., KARTHIK K., CHAKRABORTY S., TIWARI R., KAPOOR S., Kumar A., ThOMAS P., 2014. Loop-mediated isothermal amplification of DNA (LAMP): a new diagnostic tool lights the world of diagnosis of animal and human pathogens: a review. Pak. J. Biol. Sci. 17, 151-166.

Dooley J. J., PAine K. E., Garrett S. D., BRown H. M., 2004. Detection of meat species using TaqMan real-time PCR assays. Meat Sci. 68, 431-438.

FukUTA S., IIDia T., MizUKami Y., IshidA. A., UEDA J., KanBee M., Ishimoto Y., 2003. Detection of Japanese yam mosaic virus by RT-LAMP. Arch. Virol. 148, 1713-1720.

Harper S. J., WARD L., Clover G., 2010. Development of LAMP and Real-Time PCR methods for the rapid detection of Xylella fastidiosa for quarantine and field applications. Phytopathol. $100,1282-1288$.

Imai M., NinOmiYa A., MineKawa H., Notomi T., ISHIZAKI T., VAN TU P., TIEN NT, TASHIRO M., ODAGIRI T., 2007. Rapid diagnosis of H5N1 avian influenza virus infection by newly developed influenza H5 hemagglutinin gene-specific loop-mediated isothermal amplification method. J. Virol. Methods. 141, 173-180.

KaneKo H., KaWANa T., FUKUSHIMA E., SuzUTANI T., 2007. Tolerance of loop-mediated isothermal amplification to a culture medium and biological substances. J. Biochem. Biophys. Methods. 70, 499-501.

Kubota R., Vine B. G., Alvarez A. M., Jenkins D. M., 2008. Detection of Ralstonia solanacearum by Loop-Mediated Isothermal Amplification. Bacteriol. 98, 1045-1051.

Lee D., LA Mura M., AllnutT T. R., Powell W., 2009a. Detection of genetically modified organ isms (GMOs) using isothermal amplification of target DNA sequences. BMC Biotechnol. 9, 7.

Lee D., la Mura M., AllnutT T. R., Powell W., REENLAND A. G., 2009b. Isothermal amplification of genetically modified DNA sequences directly from plant tissues lowers the barriers to high-throughput and field-based genotyping. J. Agricult. Food Chem. 5, 9400-9402.

MALEWSKA A., 2005. Metody izolacji kwasów nukleinowych. [W]: Zastosowanie metod molekularnych $w$ badaniach ekologicznych. PILOT M., RUTKOWSKI R. (red.). Muzeum i Instytut Zoologii PAN, Warszawa, 26-28.

MoRADI A., NASIRI J., ABDOLlAHI H., Almasi M., 2012. Development and evaluation of a loop - mediated isothermal amplification assay for detection of Erwinia amylovora based on chromosomal DNA. Euro. J. Plant Pathol. doi: 10.1007/s10658-012-9939-y.

MORI Y., NAGAMINE K., TOMITA N., NotOMI T., 2001. Detection of loop-mediated isothermal amplification reaction by turbidity derived from magnesium pyrophosphate formation. Biochem. Biophys. Res. Commun. 289, 150-154.

Mori Y., KitaO M., TOMita N., Notomi T., 2004. Real-time turbidimetry of LAMP reaction for quantifying template DNA. J. Biochem. Biophys. Methods. 59, 145-157.

Nagamine K., Watanabe K., Ohtsuka K., Hase T., Notomi T., 2001. Loop-mediated isothermal amplification reaction using a nondenatured template. Clin. Chem. 47, 1742-1743.

NAGAmine K., Hase T., NotOmi T., 2002. Accelerated reaction by loop-mediated isothermal amplification using loop primers. Mol. Cell. Probes. 16, 223-229.

Nogami H., TSutsumi H., Komuro T., Mukoyama R., 2008. Rapid and simple sex determination method from dental pulp by loop-mediated isothermal amplification. Forensic Sci. Int. Gen. 2, 349-353.

Notomi T., Okayama H., Masubuchi H., Yonekawa T., WatanaBe K., Amino N., 2000. Loop-mediated isothermal amplification of DNA. Nucleic Acids Res. 28: E63.

PRZEWODOWSKA A., ZACHARZEWSKA B., ChOŁUJ J., TREDER K., 2015. A one step, real-time reverse transcription loop mediated isothermal amplification assay to detect Potato virus Y. Am J Potato Res. doi:10.1007/s12230-015-9430-3.

PRZYBYLSKA A., FIEDLER Ż., KUCHARCZYK H., OBREPALSKA-STEPLOWSKA A., 2015. Detection of the quarantine species Thrips palmi by loop-mediated isothermal amplification. PLOS ONE 10, e0122033.

RUdiN N., INMAN K., 2001. Admissibility standards: Science on trial in the courtroom. W: An introduction of forensic DNA analysis. CRC PRESS, USA, 183-198.

SAHOO P. R., SETHY K., MOHAPATRAAND S., PANDA D., 2016. Loop mediated isothermal amplification: An innovative gene amplification technique for animal diseases. Vet. World. EISSN: 2231-0916, 465-469.

SasaKI Y., Komatsu K., Nagumo S., 2008. Rapid detection of Panax ginseng by loop-mediated isothermal amplification and its application to authentication of Ginseng. Biol. Pharm. Bull. 31, 1806-1808.

WANG Z., GU Q, SUN H., LI H., SUN B., LIANG X., YUAN Y., LIU R., SHI Y., 2014. One-step reverse transcription loop mediated isothermal amplification assay for sensitive and rapid detection of cucurbit chlorotic yellows virus. J. Virol. Methods. 195, 63-66.

WATTHANA-PANPITUCK K., KIATPATHOMCHAI W., CHU E., PANVISAVAS N., 2014. Identification of human DNA in forensic evidence by loop-mediated isothermal amplification combined with a colorimetric gold nanoparticle hybridization probe. Int. J. Legal. Med. 128, 923-931.

Wei Q. W., Yu C., ZHANG S. Y., YANG C. Y., MIRIAM K., ZHANG W. N., DOU D. L., TAO X. R. 2012. One-step detection of Bean pod mottle virus in soybean seeds by the reverse-transcription loop-mediated isothermal amplification. Virol. J. 9, 187.

Zong X., Wang W., Wei H., Wang J., Chen X., XU L., ZHU D., TAN Y., LIU Q., 2014. Rapid detection of Prunus necrotic ringspot virus using magnetic nanoparticle-assisted reverse transcription loop-mediated isothermal amplification. J. Virol. Methods. 208, 85-89. 
Kosmos Vol. 67, 3, 565-573, 2018

\title{
Barbara Wasowicz, MarianNa SOROKA
}

Department of Genetics, Faculty of Biology, University of Szczecin, 3c Felczaka Str., 71-412 Szczecin, e-mail: marianna.soroka@usz.edu.pl

\section{LOOP MEDIATED ISOTHERMAL DNA AMPLIFICATION}

\begin{abstract}
Summary
Loop mediated isothermal amplification (LAMP technique) is an ideal response to the growing demands from molecular, diagnostic, and forensic laboratories. The LAMP technique is an attractive alternative to the conventional PCR, and allows for reduction of the analysis time up to three times. DNA polymerases used for this type of amplification have strand displacement activity, which eliminates the necessity of DNA template denaturation. By using several pairs of primers in the LAMP reaction, the amplification is more specific, and compared to PCR a greater quantity of the product is obtained. In addition, the detection is visible with the bare eyes, without the use of additional procedures. The LAMP technique is gaining significance in cases such as economic crimes, diagnosis of human and animal infectious diseases, detection of plant pathogens and identification of plant GMOs.
\end{abstract}

Key words: forsenic analysis, isithermal amplification, LAMP technique 